\title{
Young consumer perception towards family firms: Relationship building and gender
}

\author{
Joanna Bednarz, Małgorzata Bartosik-Purgat, Tomasz Jastrzębski, Giuseppe T. Cirella
}

\section{A B S T R A C T}

Objective: The objective of the article is to investigate young consumer perception of family firms (FFs) used in the process of relationship building. It also stresses the importance of gender roles within this representative group.

Research Design \& Methods: Following a literature review, a quantitative survey on a statistically representative random-cluster sample of 237 Generation Z consumers was conducted in the latter half of 2017 in Poland. The computer-assisted web interviewing method was used, and factor analysis was applied.

Findings: Results indicate that young consumers perceived FFs as reliable, long-term businesses with a humancentred approach to clients. Tradition was the attribute that distinguished FFs on the market. Gender differences played an important role in the perception of FFs.

Implications \& Recommendations: Further research should consider the influencing factors for families from external influencers. This research initiates the process of influencing young customers and can lead to a model development that would describe the specifics of Generation Z in FFs.

Contribution \& Value Added: The study should be considered a framework for identifying ways to achieve competitive advantage of family-owned companies. From a practical perspective, this is an important implication for FFs' owners and marketing managers who have noticed a growing concern of an aging target population.

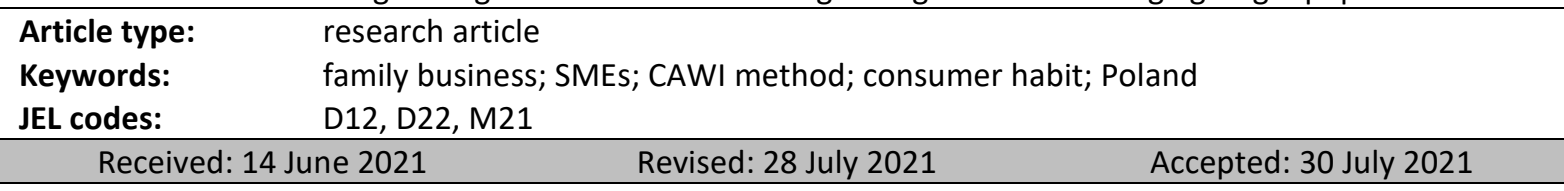

\section{Suggested citation:}

Bednarz, J., Bartosik-Purgat, M., Jastrzębski, T., \& Cirella, G.T. (2022). Young consumer perception towards family firms: Relationship building and gender. Entrepreneurial Business and Economics Review, 10(1), 161174. https://doi.org/10.15678/EBER.2022.100111

\section{INTRODUCTION}

As the backbone of the world economic system, family firms (FFs) make up an essential contribution to the economies of many countries (Beck, 2016). According to Litz (1995) and Jawed (2016) of all the business establishments from around the world more than $95 \%$ are family-run. The majority of them are found in the United States of America and Western Europe. As such, specifics of doing business communication and relationship building with consumers from different cultural contexts (Binz Astrachan et al., 2019) - merits the examination of long-lasting relational constructs of FFs with buyers in an Eastern European backdrop (i.e. where the tradition of family-owned businesses is rather new). The situation of FFs in Poland changed after 1989, with the onset of the political system's transformation and profound economic changes. From this moment, an explosion of new family businesses was visible (Wroblewska-Kazakin, 2014). Currently, the buyers of products and services offered by FFs are middleaged and elderly people. Therefore, it seems necessary for them to focus their attention on the group of younger consumers, especially Generation Z that in 2020 represented $25.5 \%$ of Poland's population (Eurostat, 2020). Two important metrics frame this notion: the numeric value of the segment and attitude to consume a high amount of goods and services (Jaciow, 2015). 
Based on market observations, FFs in Poland do not specifically concentrate on young consumers or address a clear marketing message to them (Bednarz et al., 2017). Since people belonging to this segment differ from older consumers, their needs, behaviours, and ways of communication regarding FFs require a broader investigation. As a result, companies would be better able to transform Generation $\mathrm{Z}$ representatives from potential to active customers. Moreover, a bountiful amount of literature reveals not only age but also gender as a significant factor in influencing consumer perception and behaviour towards companies and their products (Ndubisi, 2006, 2007; Guclu, 2016, Hess et al., 2016). Research into gender perception further necessitates the identification processes used to assist FFs in Poland via relationship building and communication effectiveness with this audience. The article considerations the theory of relationship building (i.e. a field of relationship marketing) with a particular emphasis on commitment-trust theory (Morgan et al., 1994). On the one hand, the article seeks to investigate young consumer perception of FFs using the process of relationship building; on the other hand, the text wishes to stress the importance of gender roles within this representative group. Exploratory research questions are considered in the methodology and are posed as the basis for the research. At length, the study could be considered a framework to identify ways to achieve competitive advantage of FFs in unfavourable conditions of an aging society and group targeting of consumers. Owners and leaders of companies must be prepared for continuous transformation and change, as they should adopt their products and communication message to specific generations.

The article first provides a literature review that examines relationship building between companies and customers - then expanding into a conceptual framework, research methodology used to develop the study, results, and a discussion that elucidates on the findings and positioning of key strengths exploitation, summarized by a conclusions section that focuses on the research opportunities and limitations.

\section{LITERATURE REVIEW}

\section{Relationships between companies and customers}

Strong rivalry among business entities on the market strives to build long-term relationships with buyers. This is the basis of relationship marketing, a contemporary paradigm in marketing literature dating back to the 1980s. Morgan et al. (1994) define relationship marketing as 'all marketing activities directed towards establishing, developing and maintaining successful relational exchanges' (p. 22). As proposed by Gupta et al. (2012), relationship marketing focuses on: (1) attracting, maintaining, and enhancing relationships between firms and customers; (2) creating, communicating, and delivering value to customers; (3) enhancing mutual economic value at a reduced cost; and (4) developing and maintaining successful relational exchanges. Murphy et al. (2007) conclude that 'due to its inclusiveness and long-term orientation, the relationship marketing paradigm is a unique construct for analysing the marketing process' (p. 39). Murphy et al. (2007) also identify in the literature a number of virtues associated with relationship marketing: honesty, fairness, benevolence, integrity, reliability, commitment, and trust. These are the building blocks of any long-term partnership; however, three of them - trust, commitment, and diligence - are key connectors with relationship marketing.

Ndubisi et al. (2018) provides a summary of the earliest works on the concept and lists several theoretical perspectives that were applied towards the understanding of firm-customer relationships, namely the commitment-trust perspective, relational norms perspective, dependence perspective, transaction cost economics perspective, social network theory, game theory, political economy perspective, knowledge-based view of the firm, and dynamic capability perspective. This article will focus on the commitment-trust theory as the root source of relationships since 'trust and commitment [act] as hallmarks' (Ndubisi et al., 2018, p. 927) in terms of satisfaction. Solomon et al. (2001) underline that trust results from dialogue, which they describe as conversations about trust. Trust stimulates the communication that makes commitments possible (Murphy et al., 2007). Companies try to attract new customers to buy goods and services by offering special or even unique attributes important to buyers. Building long-term, strong relationships is advantageous both for the company and customer since they are mutually satisfying and beneficial. Throughout Eastern Europe, the transformation processes dating back to the early 
1990s has seen a continual and sharp growth in the number of FFs (Wroblewska-Kazakin, 2014). In Poland, the family-based nature of companies is generally not highlighted in marketing communication activities. The reason for this behaviour is a lack of awareness and conviction (Leszczewska et al., 2017) that family ownership and management are powerful enough and can be perceived as a positive message in relation to stakeholders, especially with customers. As a result, there is a significant gap in communication of FFs in the marketplace. This gap should be seen as an opportunity for family-owned businesses to build a powerful marketing message. It is important since FFs can benefit from informing their customers that they are family-run business. Researchers from different countries emphasize that promoting the family origin of a company, its unique history, identity, and inimitable values causes positive differentiations and associations among stakeholders, especially in comparison with non-family entities (Botero et al., 2010; Carrigan et al., 2008; Orth et al., 2009; Zellweger et al., 2010; Alonso et al. 2018). This approach contributes to building a distinct family and corporate reputation, and it can trigger a certain set of associations (e.g. a branding message (Barroso Martínez et al., 2019; Binz Astrachan et al., 2018) by distinguishing FFs from their non-family competitors in terms of product influence by developing a unique and sustained competitive advantage (Binz Astrachan et al., 2013).

Potentially successful communicative means, such as branding messages, can favour the market share of FFs. At present, FFs in Poland are associated with a high level of confidence, offering high quality products and services (Marjański, 2015; Dacko-Pikiewicz, 2019). Products and services should be used as the main carrier of brand identity - inclusive of the communication message of long-lasting family tradition as a guarantee of high quality (Wielsma et al., 2019). Zanon et al. (2019) indicate that FFs often focus on building strong social ties and close relationships with stakeholders, consumers in particular. Cooper et al. (2005) even declare that 'relationships are at the heart of family business' ( $p .242)$. Customers generally perceive FFs as traditional, trustworthy, credible, and consumer-oriented, but also social and fair (Carrigan et al., 2008; Cooper et al. 2005). Family businesses evoke positive associations and a sense of authenticity and reliability. The flexibility and adaptability to dynamic changes in accordance with market conditions make FFs more survival-oriented since they possess a sense of responsibility for the family, employees, and the local community in which they operate (Wach, 2020). This cause and effect often position FFs as more ethical than non-family companies (Leszczewska et al., 2017), which increases customer intention to engage in long-term relationships that can positively affect their loyalty, purchase frequency and word-of-mouth advertisement. The owners and leaders of FFs in Poland now face a serious problem related to generational change. The change is twofold. On the one hand, there is a generational challenge of passing down company management (i.e. the duality of being a part of the family and member of the firm). On the other, there is a clear problem regarding the aging of current customers and planning for the specificity and expectation of younger buyers. These two changes in direction require an attention to detail that must consider relationship building via different mentality, system of values, and communication (Aragón-Amonarriz et al., 2019). All FFs face this process of succession and are obliged to focus their attention on not losing existing customers while attracting representatives of younger generations. When a young manager (successor) takes over an FF, a number of difficulties emerge due to the possible lack of generational understanding, contacts (network), and experience.

\section{Conceptual development: Segment of young consumers}

The segment of so-called young consumers is the subject studies and analyses. They are a forwardlooking and attractive group for companies as potential buyers. This article understands young consumers as representatives of Generation Z, also called Generation M (multitasking) or the net generation (Angus, 2018; Kilian et al., 2012; Gentilviso et al., 2019) who are people born after 1993 (Turner, 2015). The most indicated paths of research, in relation to this segment of the population, are twofold: consumers and employees (Anantatmula et al., 2012; Zhang et al., 2017; Soares et al., 2017). As such, representatives of young consumers are people born in times of the dynamic growth of the Internet services and related communication technologies, e.g. video chat (Parry et al., 2019). This segment of the population has been exposed to this innovative change since birth. The Internet is part of Generation Z's natural environment, and it is essential for efficient functioning (Parry et al., 2019). In almost every area of life, they use technology and digital media; they function efficiently in the global village 
that allows them to confidently communicate with persons from all over the world. They are very active users of social media which is where they share information about their lives (Bilgihan et al., 2014; Bravo et al. 2006; Jovevski and Vasilevski, 2019). They are demanding as consumers, searching for information about products and making purchases online (Danaher et al., 2011; Triantafillidou et al., 2018; Gentilviso et al., 2019). They are well-educated, energetic, competitive, curious, and ready to develop further, which undoubtedly makes them self-confident (Luttrell et al., 2016).

\section{Gender: A differential variable}

Gender is perceived as a significant moderating variable especially in research associated with consumer behaviour and management (Rosener, 1990; Powell et al., 1997; Lim et al. 2014; Fernández, 2015). For the purpose of this study, the importance of gender captures consumer decisions, relationship building and online communication, social platforms and online shopping - all vital for Generation Z. Results from a number of studies show that gender is an imperative factor in the trust building mechanisms in social media (Nadkarni et al., 2012; Sun et al., 2018). Generally, women use social platforms more often than men for communication and information gathering (Nadkarni et al., 2012). Lim et al. (2014) also emphasize the women tend to use social media to communicate with friends, while men use it for shopping or expressing opinion. This situation is most probably connected with the fact that women are less risk-oriented than men and appreciate the ability to respond appropriately to information and posts appearing online (See-To et al., 2014). Sun et al. (2018) explore the trust building mechanisms (i.e. institution- and transference-based trust building) in social media in relation to gender differences. They prove that the 'regulatory effectiveness affects competence- and characterbased trust and these impacts are stronger for men than for women' (Sun et al., 2018, p. 498). As a result, competence-based trust is more significant for men, while character-based trust is more pronounced among women. In fact, Bergagna et al. (2018) state that women spend more time daily on Facebook than men. They argue that this connection correlates with the tendency for women to be more socially interactive. Moreover, women are more successful in expressing themselves, establishing communication and recognizing various stimulators (Guclu, 2016; Polce-Lynch et al., 1998). Investigations of gender differences in the area of entrepreneurial potential of younger people find, in a general sense, stronger personal competencies among women than among men. Women perform better than men when searching for data and information, both when committing to a work contract and when achieving business (high-quality work) objectives (Lazányi, 2014).

\section{Conceptual framework}

Based on the literature, we may delineate the characteristic of FFs and young consumers. However, we found no scientific articles that describe the process of and how to build relationships between FFs and young consumers. This gap is a significant challenge for FFs to inform younger generations about their business, unique history, inimitable identity, and values that are core elements in building sustainable competitive advantage (Cooper et al., 2005; Zanon et al., 2019), distinctive to non-family competitors (Binz Astrachan et al., 2013; Binz Astrachan et al., 2018). This can be used by FFs to create the well-adapted concept of communicative messages (Bartosik-Purgat, 2019b; Florenthal, 2019), keeping in mind that characteristics (i.e. young consumers and potential differences between the genders) affect relationship building, trust, and commitment regarding the future of FFs (Aragón-Amonarriz et al., 2019; Murphy et al., 2007; Ndubisi et al., 2018; Morgan et al., 1994; Moorman et al., 1992). Based on the literature, we propose the below conceptual framework (Figure 1).

In support of the framework, we developed three research questions and two hypotheses to provide for the research gaps.

RQ1: How young customers perceive FFs?

RQ2: What significant attributes young consumers expect of FFs for building long-lasting relation-ships?

RQ3: What is the significance of gender in the perception of FFs? 


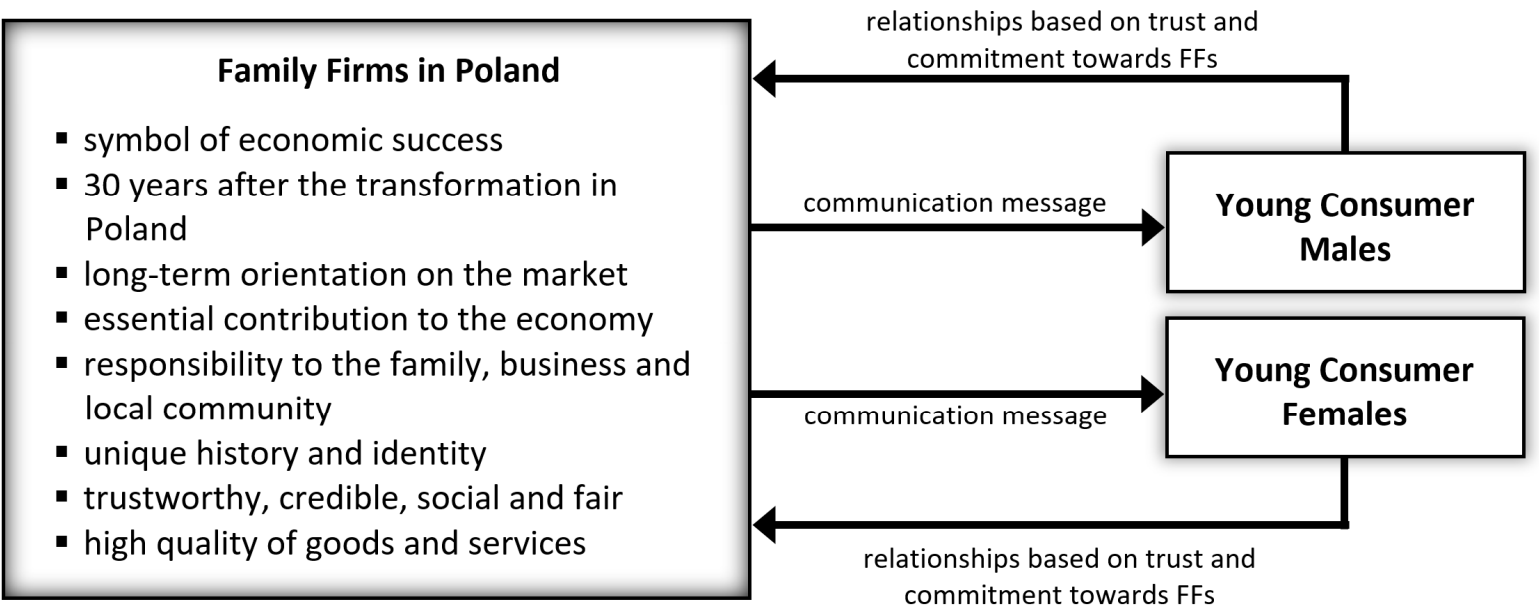

Figure 1. Conceptual framework

Source: own elaboration.

The hypotheses were formulated based on the literature review. Firstly, young consumers are demanding, self-confident, curious, and searching for information about products on the Internet (Danaher et al., 2011; Triantafillidou et al., 2018; Gentilviso et al., 2019; Luttrell et al., 2016). Secondly, competence-based trust is more significant for men (Sun et al., 2018). Therefore, we posti that:

H1: Young customers tend to perceive FFs as dependable suppliers of goods and services of decent to high quality.

H2: Young men have a more positive association with FFs than young women.

\section{RESEARCH METHODOLOGY}

\section{Sample Data}

In order to answer and test our research questions, we prepared a questionnaire-based survey to gather the data needed to identify a set of attributes specific to FFs in Poland and assess the importance of building relationships with Generation Z consumers. A quantitative survey using a statistically representative random-cluster sample of 1091 consumers was conducted in January 2018 in Poland. A computer-assisted web interviewing (CAWI) method was applied with the support of an external company, ABM Marketing Research Agency based in Warsaw, Poland. The sample reflected statistics on age, gender, and place of residence by using nationwide population multivariate distribution from Statistics Poland. Just over a quarter of the sample (26\%) was a sub-segment of young buyers aged 16-25 (273 respondents), which was utilized as our representative sample. We used the online survey (with three filters). The statistical significance level was $\alpha=0.05$ and the measurement error equalled $2.97 \%$ (Table 1 ).

Table 1. Demographic characteristics of the Generation $Z$ respondents

\begin{tabular}{|l|l|l|}
\hline \multicolumn{1}{|c|}{ Characteristics } & \multicolumn{1}{c|}{ Frequency } & \multicolumn{1}{c|}{ Percentage (\%) } \\
\hline Female & 135 & 49.45 \\
\hline Male & 138 & 50.55 \\
\hline Total & 273 & 100 \\
\hline
\end{tabular}

Source: own study.

To prepare the questions and answers for the questionnaire, we conducted qualitative research in three stages. First, a critical analysis of the literature was conducted in preparation for the expert interviews. Second, latent participant observation was used as a research method (i.e. between May and June 
2017) where 40 customers were observed and randomly chosen in natural surrounding (e.g. retail outlets). From these customers, observational notes were taken from ten FF locations in which product purchases were categorized to understand everyday buyer behaviour. Third, individual in-depth semi-structured interviews were conducted (i.e. between July and October 2017) in order to identify buyer knowledge, emotions and purchasing decisions respective of FFs. Eight respondents (i.e. three women and five men) belonging to Generation $Z$ (i.e. the convenient sample) were tested. As a key result, 14 attributes associated with FFs as well as six statements were identified. To assess the degree of compliance of the respondents, a five-point Likert scale was applied, where: $5=$ strongly agree; 4=rather agree; $3=$ neither agree nor disagree; $2=$ rather disagree; $1=$ strongly disagree. Finally, before the quantitative survey, a pilot CAWI study of 30 respondents was conducted in order to check for adequacy and intelligibility.

\section{RESULTS AND DISCUSSION}

First, an exploratory factor analysis was conducted to determine the perception of FFs by using young generation data from the survey. Second, a two-sample t-test for a difference in mean was calculated to compare responses for gender regarding their associations with FFs and preferences regarding individual products (Table 2). From the survey results, two questions in particular were applied to develop a set of tabular results: question 6 (What do you associate with FFs?) and question 11 (Please point out how much you agree or disagree with the following statements about FFs in Poland). These questions correlated with RQ1 by focusing on how respondents perceived family-owned businesses in Poland. Examining the set of responses of young consumers, three factors (1-3) have been identified and interpreted as positive (Factor 1), negative (Factor 2), and neutral (Factor 3 ). The features that made up the positive Factor 1 (28\%) for building relationships between FFs and young consumers included reliability, passing on the FF from generation to generation, operating on the market for a long time, Polish origin of products, tradition, a 'human' approach to clients, high quality of products and careful workmanship, and finally, the fact that FFs are good for the local community. These results lead to the conclusion that young consumers perceive family businesses as dependable suppliers of goods and services of decent and high quality, thus confirming $\mathrm{H} 1$. The negative Factor 2 (11\%) featured three points: the possibility of incompatibilities of the family owning the FF, underinvestment, and nepotism. The neutral factor Factor $3(13 \%)$ - which can be defined as a neutral attitude of respondents to FFs included statements such as: FFs must be supported because they pay taxes in Poland, Poles lack awareness about supporting Polish capital, FFs should promote the fact that they are family-owned, and customers are willing to be informed that a FF produced a product. Young consumers that did not conform to any one of the three factors equalled $48 \%$.

In terms of RQ2, the identified features could be extracted from the positive Factor 1 in Table 2, including: high quality products and careful workmanship (0.81), tradition (0.78), 'human' approach to the client (0.78), and reliability (0.75). For young consumers, the information that products are Polish and homemade and the fact that FFs are good for the local community are also important (0.72). Moreover, young buyers further emphasized that family businesses developed from generation to generation (0.71), and thus, they maintained a long presence on the market (0.68). In terms of gender, we determined differences in the perception of FFs between men and women (Table 3 ). The positive features of FFs for young men showed a strong correlation towards companies being managed by family members and that goods and services are slightly more expensive. These associations go together with men's belief in the reliability of goods and services offered by FFs. In turn, women focused their on organic products offered by FFs.

In order to expand the analysis, we looked at the similarities and differences in the perception of FFs by gender to examine RQ3. We conducted a two-sample t-test for a difference in mean for question 6 of the survey. The results showed that men more strongly than women associate FFs with reliability, business development from generation to generation, operating on the market for a long time, tradition, and a 'human' approach to clients. Moreover, women more than men positioned the key problem associated with FFs with an incompatibility in the family core. For the remaining features of FFs, the differences in their association by gender were not statistically significant. The results indicated that 
Table 2. Factor analysis of the perception of FFs by young consumers aged $16-25^{\dagger}$

\begin{tabular}{|c|c|c|c|c|c|c|c|c|c|}
\hline Respondents aged $16-25$ & & All & & & Men & & & Womer & \\
\hline Variables characterizing perception of FFs & Fa. 1 & Fa. 2 & Fa. 3 & Fa. 1 & Fa. 2 & Fa. 3 & Fa. 1 & Fa. 2 & Fa. 3 \\
\hline Reliability & 0.75 & -0.04 & 0.19 & 0.80 & 0.01 & 0.17 & 0.70 & -0.09 & 0.19 \\
\hline Relations, family managed & 0.52 & 0.05 & 0.15 & 0.72 & -0.05 & 0.14 & 0.20 & 0.12 & 0.43 \\
\hline Generational business practice & 0.71 & 0.02 & 0.09 & 0.75 & 0.00 & 0.01 & 0.58 & 0.08 & 0.35 \\
\hline Long term operation & 0.68 & -0.04 & -0.05 & 0.63 & 0.07 & 0.08 & 0.71 & -0.07 & -0.10 \\
\hline Organically made products & 0.63 & 0.07 & 0.07 & 0.60 & 0.28 & 0.14 & 0.71 & -0.13 & -0.06 \\
\hline Goods, services more expensive & 0.45 & 0.40 & -0.01 & 0.65 & 0.33 & -0.04 & 0.19 & 0.45 & 0.19 \\
\hline Polish, homemade products & 0.72 & 0.04 & 0.23 & 0.69 & 0.16 & 0.15 & 0.73 & -0.05 & 0.34 \\
\hline Tradition & 0.78 & -0.08 & 0.22 & 0.79 & -0.07 & 0.10 & 0.77 & -0.08 & 0.34 \\
\hline Internal family business problems, incompatibility & -0.05 & 0.76 & -0.11 & 0.03 & 0.75 & -0.09 & -0.10 & 0.75 & -0.15 \\
\hline Underinvestment & -0.04 & 0.77 & 0.06 & -0.03 & 0.77 & 0.02 & -0.02 & 0.75 & 0.01 \\
\hline Nepotism, favouring of the family & 0.04 & 0.78 & -0.12 & 0.12 & 0.74 & -0.09 & -0.04 & 0.79 & -0.10 \\
\hline ‘Human’ approach to customers & 0.78 & 0.00 & 0.19 & 0.72 & 0.02 & 0.26 & 0.83 & 0.04 & 0.17 \\
\hline High quality products and craftmanship & 0.81 & 0.01 & 0.10 & 0.82 & 0.04 & 0.07 & 0.81 & 0.04 & 0.15 \\
\hline Good for local community development & 0.72 & 0.00 & 0.24 & 0.71 & -0.04 & 0.21 & 0.74 & 0.02 & 0.29 \\
\hline FFs must be supported because they pay taxes in Poland & 0.30 & -0.09 & 0.78 & 0.26 & -0.11 & 0.74 & 0.31 & -0.09 & 0.76 \\
\hline Poles are not aware of supporting Polish capital & -0.02 & 0.09 & 0.66 & 0.02 & 0.08 & 0.64 & -0.06 & 0.00 & 0.63 \\
\hline $\begin{array}{l}\text { FFs support each other and cooperate closely with each } \\
\text { other }\end{array}$ & 0.39 & -0.02 & 0.14 & 0.19 & 0.14 & 0.28 & 0.61 & -0.10 & -0.03 \\
\hline FFs promote they are family owned & 0.15 & -0.12 & 0.77 & 0.07 & -0.17 & 0.70 & 0.21 & -0.09 & 0.80 \\
\hline $\begin{array}{l}\text { When shopping, people should know that the product } \\
\text { comes from FF }\end{array}$ & 0.27 & 0.02 & 0.74 & 0.24 & 0.09 & 0.75 & 0.25 & -0.05 & 0.72 \\
\hline FF products are generally purchased by older clientele & -0.02 & 0.47 & 0.22 & 0.01 & 0.52 & 0.32 & -0.02 & 0.34 & 0.02 \\
\hline Eigenvalues & 5.67 & 2.20 & 2.57 & 5.87 & 2.29 & 2.46 & 5.51 & 2.16 & 2.91 \\
\hline Share of explained variance & 0.28 & 0.11 & 0.13 & 0.29 & 0.11 & 0.12 & 0.28 & 0.11 & 0.15 \\
\hline
\end{tabular}

Table 3. Associations of young consumers aged 16-25 with $\mathrm{FFs}^{\dagger}$

\begin{tabular}{|l|c|c|c|c|c|c|}
\hline \multicolumn{1}{|c|}{ What do you associate with FFs? } & $\begin{array}{c}\text { Mean } \\
\text { for men }\end{array}$ & $\begin{array}{c}\text { Mean for } \\
\text { women }\end{array}$ & Stat. $\mathbf{t}$ & $\begin{array}{c}\text { p-value } \boldsymbol{H}_{\boldsymbol{A}}: \\
\boldsymbol{\mu}_{\boldsymbol{M}} \neq \boldsymbol{\mu}_{\boldsymbol{F}}\end{array}$ & $\begin{array}{c}\mathbf{p} \text {-value } \boldsymbol{H}_{\boldsymbol{A}}: \boldsymbol{\mu}_{\boldsymbol{M}}<\boldsymbol{\mu}_{\boldsymbol{F}} \\
\boldsymbol{\mu}_{\boldsymbol{M}}>\boldsymbol{\mu}_{\boldsymbol{F}}\end{array}$ \\
\hline Reliability & 3.52 & 3.30 & 2.16 & $\mathbf{0 . 0 3 2}$ & 0.984 & $\mathbf{0 . 0 1 6}$ \\
\hline Relations, managed by family members & 3.81 & 3.86 & -0.45 & 0.655 & 0.328 & 0.672 \\
\hline Passes from generation to generation & 3.99 & 3.83 & 1.41 & 0.161 & 0.920 & $\mathbf{0 . 0 8 0}$ \\
\hline Operates on the market for a long time & 3.44 & 3.15 & 2.34 & $\mathbf{0 . 0 2 0}$ & 0.990 & $\mathbf{0 . 0 1 0}$ \\
\hline Organic products & 3.10 & 3.05 & 0.43 & 0.666 & 0.667 & 0.333 \\
\hline Goods, services slightly more expensive & 3.44 & 3.50 & -0.58 & 0.562 & 0.281 & 0.719 \\
\hline Polish, homely products & 3.48 & 3.50 & -0.15 & 0.877 & 0.438 & 0.562 \\
\hline Tradition & 3.93 & 3.63 & 2.76 & $\mathbf{0 . 0 0 6}$ & 0.997 & $\mathbf{0 . 0 0 3}$ \\
\hline With problems (incompatibilities in the family) & 2.52 & 2.71 & -1.52 & 0.130 & $\mathbf{0 . 0 6 5}$ & 0.935 \\
\hline Underinvested & 2.78 & 2.84 & -0.55 & 0.580 & 0.290 & 0.710 \\
\hline Nepotism (favouring family members) & 3.03 & 3.19 & -1.18 & 0.240 & 0.120 & 0.880 \\
\hline ‘Human' approach to the client & 3.60 & 3.41 & 1.74 & $\mathbf{0 . 0 8 2}$ & 0.959 & $\mathbf{0 . 0 4 1}$ \\
\hline High quality products, careful workmanship & 3.44 & 3.30 & 1.23 & 0.219 & 0.891 & 0.109 \\
\hline Good for the local community & 3.59 & 3.56 & 0.26 & 0.796 & 0.602 & 0.398 \\
\hline
\end{tabular}

${ }^{\dagger}$ Means for genders and results of two-sample t-test for a difference in mean

Source: own elaboration with the R environment.

men perceive family businesses better than women, which supports hypothesis H2. The results for RQ3 considered gender difference sensitivity of producers for the sector in which FFs operated. We conducted a twosample t-test to calculate the difference in mean for question 1 (While buying products from the following categories, do you pay attention to the manufacturer or brand owner?) (Table 4). It turned out that men pay 
more attention to the manufacturer and brand owner than women. In particular, statistically significant differences concerned the following products: food, clothing and footwear, toys and supplies for children, cosmetics, but also gastronomy and catering.

Table 4. Importance of the manufacturer brands of products and services from separate categories of people aged $16-25^{\dagger}$

\begin{tabular}{|l|c|c|c|c|c|c|}
\hline $\begin{array}{c}\text { While buying products from the following } \\
\text { categories, do you pay attention to the man- } \\
\text { ufacturer/brand owner? }\end{array}$ & $\begin{array}{c}\text { Mean } \\
\text { for men }\end{array}$ & $\begin{array}{c}\text { Mean for } \\
\text { women }\end{array}$ & Stat. t & $\begin{array}{c}\mathbf{p} \text {-value } \boldsymbol{H}_{\boldsymbol{A}}: \\
\boldsymbol{\mu}_{\boldsymbol{M}} \neq \boldsymbol{\mu}_{\boldsymbol{F}}\end{array}$ & $\left.\begin{array}{c}\mathbf{p} \text {-value } \boldsymbol{H}_{\boldsymbol{A}}: \boldsymbol{\mu}_{\boldsymbol{M}}<\boldsymbol{\mu}_{\boldsymbol{F}} \\
\mathbf{p} \text {-value } \boldsymbol{H}_{\boldsymbol{A}}:\end{array}\right) \boldsymbol{\mu}_{\boldsymbol{M}}>\boldsymbol{\mu}_{\boldsymbol{F}}$ \\
\hline Food products & 4.21 & 3.93 & 2.56 & $\mathbf{0 . 0 1 1}$ & 0.994 & $\mathbf{0 . 0 0 6}$ \\
\hline Clothing, footwear & 4.19 & 3.94 & 2.16 & $\mathbf{0 . 0 3 2}$ & 0.984 & $\mathbf{0 . 0 1 6}$ \\
\hline Toys and supplies for children & 4.10 & 3.68 & 2.55 & $\mathbf{0 . 0 1 1}$ & 0.994 & $\mathbf{0 . 0 0 6}$ \\
\hline Furniture, interior items & 3.61 & 3.77 & -1.12 & 0.263 & 0.131 & 0.869 \\
\hline Construction, renovation, transport services etc. & 4.27 & 4.08 & 1.24 & 0.216 & 0.892 & 0.108 \\
\hline $\begin{array}{l}\text { Craft services, e.g. optician, hairdresser, } \\
\text { watchmaker }\end{array}$ & 3.90 & 3.72 & 1.23 & 0.220 & 0.890 & 0.110 \\
\hline Cosmetics & 4.43 & 3.74 & 6.06 & $\mathbf{0 . 0 0 0}$ & 1.000 & $\mathbf{0 . 0 0 0}$ \\
\hline Hotel services, guest houses, agritourism & 4.04 & 3.92 & 0.73 & 0.465 & 0.767 & 0.233 \\
\hline Gastronomy, catering & 4.08 & 3.79 & 2.23 & $\mathbf{0 . 0 2 7}$ & 0.987 & $\mathbf{0 . 0 1 3}$ \\
\hline
\end{tabular}

${ }^{+}$Means for gender and results of two-sample t-test for a difference in mean

Source: own elaboration with the R environment.

Results obtained from the research clearly confirmed that Generation Z consumers notice the distinct role of FFs, which combined three elements: long-term orientation on the market, family ownership (firm development from generation to generation), and commitment to the local community (Aragón-Amonarriz et al., 2019; Deloitte, 2019; Wach, 2020). Conclusions from the literature indicated that FFs generally do not engage in formal customer relationship management initiatives (Cooper et al., 2005; Miller et al., 2001). This situation seems to be worse in Poland where FFs do not emphasize their family nature in marketing communication due to the lack of awareness or conviction (Leszczewska et al., 2017). This significant gap should be treated as a great opportunity for family-owned businesses to build powerful messages addressed to different segments of society. Specifically, the need to develop a communicative message to young people is vital for the prospect of future buyers in Poland (Eurostat, 2020). Our findings demonstrate that young consumers, aged 16-25, have a strong positive approach towards FFs. Even though young consumers are generally sceptical, doubting, and distrustful, they treat FFs as reliable partners (Nikodemska-Wolowik et al., 2019; Marjanski, 2015) and as more customer-oriented than non-family businesses (Cooper et al., 2005). Generation $Z$ consumers clearly stated that while shopping, it was worth knowing that products that originate from family-owned companies should be advertised as such - as they would view this message positively (Alonso Dos Santos et al. 2020).

Moreover, the research conducted by Alonso Dos Santos et al. (2020) indicates that the 'family attribute' increases trust and purchase interest among consumers. As such, the 'family nature' of FFs can become a fundamental and exceptional resource thanks to their unique and inimitable history and identity (Binz Astrachan et al., 2018). These arguments can be used to develop exclusive and sustained competitive advantage and differentiation (Binz Astrachan et al., 2013; Shen \&-Tikoo, 2020; Lude \& Prügl, 2018). However, others clearly stress that the distinct communication of this fact is still strongly needed (Shen \& Tikoo, 2020). As such, key attributes based on the findings should be used while preparing a communication message. Firstly, FFs should highlight Polish and homemade products of high quality and careful workmanship, together with their tradition and reliability (Wielsma et al., 2019; Zanon et al., 2019). In Poland, the trend of returning to tradition has been clearly visible for several years now, which is especially visible in the food sector, in which natural ingredients, traditional recipes, and own production methods are welcome and even expected (Nikodemska-Wolowik \& Bednarz, 2019; Nikodemska-Wołowik et al., 2020). Moreover, young buyer attention is also attracted to the special 'human' approach to customer care. This is often found in FFs that operate on the market for 
a long-time and develop from generation to generation, thus creating a customer-friendly association (Cooper et al., 2005). As a result, FFs should also stress their care for and embeddedness in the local community. Young men are linked to information about relationships internally managed within the community at large. This can be stressed by buyers who accept goods and services at a slightly higher price than usual (Carrigan et al., 2008). In sum, the above attributes should be treated by recipients as added value to the FF brand message (Binz Astrachan et al., 2019).

\section{CONCLUSIONS}

At the community level, the research could be extended to external influencers like peers, friends, and the mass media since they also play a fundamental role in the process of influencing young customers. The expectations of young people regarding products and brands change more frequently than changes in general skills and attitudes (Moore-Shay et al., 1988). An appropriately long viewed research perspective should be adopted to notice these changes. The combination of all external influencers may lead researchers to an in-depth scientific model that describes the specifics of the Generation Z segment, one useful also in relation to FFs. Incidentally, this may have a theoretical implication both for theoreticians and practitioners, especially in the context of building trust and commitment. We should not overlook the fact that FFs are also associated with nepotism, internal struggles (e.g. incompatibility issues in the family), and underinvestment. These negative connotations were identified only by a small number of respondents; however, it would be valuable to further explore the reasons for these opinions so as to understand their sources. Another issue that was not investigated was the question of how to communicate with young buyers. Communication with young buyers can happen via various channels (i.e. directly or indirectly), media, and devices because young people are active users of social media (Bilgihan et al., 2014; Zhang et al., 2017) and new communication technologies that were always present in their lives (Parry et al., 2019; Bartosik-Purgat, 2019a). Thus, we should concentrate on interactivity as the main feature of attracting young buyers, giving them the ability to respond quickly, send feedback, and express opinion (Andersen, 2001). This manner of communication will help FFs to build relationship, trust, and commitment with young buyers (Balaji et al., 2016; Hänninen et al., 2017), which will in turn significantly expand the research area and provide a fuller picture for FFs' development.

While the study provides useful insights about perception of FFs by Generation Z consumers, the study limitations include the relatively small study sample specific to Generation Z. Expanding the sample size and redefining young consumers to include Generation $Y$ would be a noteworthy adjustment of our study, as it would allow for comparative findings between the two segments since portions of Generation $Y$ will soon begin to start having families and children of their own (Kvidahl, 2015). Finally, it would be interesting to determine and describe any differences between these two segments and to evaluate gender differences in correlation to age since a sixteen- and twenty-five-year-old can have very different views and needs. To further strengthen the methodology, future research should define additional characteristics in terms of relationships based on trust and commitment towards FFs. Consumer behaviour research can differ depending on such definitional differences. However, exceptional and favourable conditions should not allow FFs to feel overly comfortable. Family businesses must recognize well in advance that younger generations will also demand improved service and product development, along with an efficient offer and communication message addressed directly to them. Only such an awareness will allow FFs to gain and consolidate market share and competitive advantage.

\section{REFERENCES}

Alonso, A.D., Kok, S., \& O’Shea, M. (2018). Family Businesses and Adaptation: A Dynamic Capabilities Approach. Journal of Family and Economic Issues, 39, 683-698. https://doi.org/10.1007/s10834-018-9586-3

Alonso Dos Santos, M., Llanos Contreras, O., Calabuig Moreno, F., \& Augusto Felicio, J. (2020). Should a family firm communicate their family identity and country of origin? A cross-cultural study from Chile and Spain. Inter-national Journal of Emerging Markets, Vol. ahead-of-print No. ahead-of-print. https://doi.org/10.1108/IJOEM-01-2020-0027. 
Anantatmula, V.S., \& Shrivastav, B. (2012). Evolution of project teams for Generation Y workforce. International Journal of Managing Projects in Business, 5(1), 9-26.

Andersen, P.H. (2001). Relationship development and marketing communication: An integrative model. Journal of Business \& Industrial Marketing, 16(3), 167-182. https://doi.org/10.1108/08858620110389786

Angus, A. (2018). Top 10 global consumer trends for 2018 emerging forces shaping consumer behaviour. London: Euromonitor International.

Aragón-Amonarriz, C., Arredondo, A.M., \& Iturrioz-Landart, C. (2019). How Can Responsible Family Ownership be Sustained Across Generations? A Family Social Capital Approach. Journal of Business Ethics, 159(1), 161185. https://doi.org/10.1007/s10551-017-3728-7

Balaji, M.S., Roy, S.K., \& Wei, K.K. (2016). Does relationship communication matter in B2C service relationships? Journal of Services Marketing, 30(2), 186-200. https://doi.org/10.1108/JSM-08-2014-0290

Barroso Martínez, A., Sanguino Galván, R., Botero I.C., González-López, Ó.R., \& Buenadicha, M. (2019). Exploring family business brands: Understanding predictors and effects. Journal of Family Business Strategy, 10(1), 5768. https://doi.org/10.1016/j.jfbs.2019.01.005

Bartosik-Purgat, M. (2019a). Digital Marketing Communication from the Perspective of Individual Consumers: A Cross-Country Comparison. Entrepreneurial Business and Economics Review, 7(3), 205-220. https://doi.org/10.15678/EBER.2019.070311

Bartosik-Purgat, M. (2019b). New media in the marketing communication of enterprises in the international market. Warsaw: PWN Publ.

Beck, S. (2016). Brand management research in family firms. Journal of Family Business Management, 6(3), 225250. http://dx.doi.org/10.1108/JFBM-02-2016-0002

Bednarz, J., \& Nikodemska-Wolowik, A. M. (2017). Family enterprises in Polish consumers' mindset in the light of international tendencies. Journal of Economics and Management, 29(3), 5-22. https://doi.org/10.22367/jem.2017.29.01

Bergagna, E., \& Tartaglia, S. (2018). Self-Esteem, Social Comparison, and Facebook Use. Europe's Journal of Psychology, 14(4), 831-845. https://doi.org/10.5964/ejop.v14i4.1592

Bilgihan, A., Peng, C., \& Kandampully, J. (2014). Generation Y's dining information seeking and sharing behavior on social networking sites. International Journal of Contemporary Hospitality Management, 26(3), 349-366. https://doi.org/10.1108/IJCHM-11-2012-0220

Binz Astrachan C., Botero, I., Astrachan, J.H., \& Prügl, R. (2018). Branding the family firm: A review, integrative framework proposal, and research agenda. Journal of Family Business Strategy, 9(1), 2-6. https://doi.org/10.1016/j.jfbs.2018.01.002

Binz Astrachan, C., Prügl, R., Hair Jr., J.F., \& Babin, B.J. (2019). Marketing and branding in family business: Assessing the landscape and charting a path forward. Journal of Family Business Strategy, 10(1), 3-7. https://doi.org/10.1016/j.jfbs.2019.02.003

Binz Astrachan, C., Hair Jr., J.F., Pieper, T.M., \& Baldauf, A. (2013). Exploring the effect of distinct family firm reputation on consumers' preferences, Journal of Family Business Strategy, 4(1), 3-11, https://doi.org/10.1016/j.jfbs.2012.12.004

Botero, I., \& Blombäck, A. (2010). Leveraging the family brand: Using brand management to highlight the advantages of family firms. Tenth Annual International Family Enterprise Research Association Conference. Lancaster: 14 July 2010.

Bravo, R., Fraj, E., \& Martínez, E. (2006). Modelling the Process of Family Influence on the Young Adult Consumer Behaviour. Journal of International Consumer Marketing, 19(1), 35-56. https://doi.org/10.1300/J046v19n01_03

Carrigan, M., \& Buckley, J. (2008). What's so special about family business? An exploratory study of UK and Irish consumer experiences of family businesses. International Journal of Consumer Studies, 32(6), 656-666. https://doi.org/10.1111/j.1470-6431.2008.00696.x

Cooper M.J., Upton N., \& Seaman S. (2005). Customer Relationship Management: A Comparative Analysis of Family and Nonfamily Business Practices. Journal of Small Business Management, 43(3), 242-256. https://doi.org/10.1111/j.1540-627X.2005.00136.x

Dacko-Pikiewicz, Z. (2019). Building a family business brand in the context of the concept of stakeholder-oriented value. Forum Scientiae Oeconomia, 7(2), 37-51. https://doi.org/10.23762/FSO_VOL7_NO2_3 
Danaher P.J., \& Rossiter J.R. (2011). Comparing perceptions of marketing communication channels. European Journal of Marketing, 45(1/2), 6-42. https://doi.org/10.1108/03090561111095586

Deloitte (2019). Long-term goals, meet short-term drive. Global family business survey 2019. New York: Deloitte Touche Tohmatsu Limited.

Eurostat. (2020), Population statistics as of 1 January 2020 by age group. Eurostat. Retrieved from http://www.eurostat.eu/ on 5 July 2021.

Fernández, J. (2015). The impact of gender diversity in foreign subsidiaries' innovation outputs. International Journal of Gender and Entrepreneurship, 7(2), 148-167. https://doi.org/10.1108/IJGE-07-2014-0022

Florenthal, B. (2019). Young consumers' motivational drivers of brand engagement behavior on social media sites. Journal of Research in Interactive Marketing, 13(3), 351-391. https://doi.org/10.1108/JRIM-05-2018-0064

Gentilviso, C., \& Aikat, D. (2019). Embracing the Visual, Verbal, and Viral Media: How Post-Millennial Consumption Habits are Reshaping the News. In Schulz, J., Robinson, L., Khilnani, A., Baldwin, J., Pait, H., Williams, A., Davis, J. and Ignatow, G. (Eds.), Mediated Millennials: Studies in Media and Communications, Vol. 19 (pp. 147-171). Bingley, West Yorkshire: Emerald Publishing Limited. https://doi.org/10.1108/S2050206020190000019009

Guclu, S. (2016). An experimental study towards young adults: Communication skills education. Eurasian Journal of Educational Research, 63, 279-292. http://dx.doi.org/ 10.14689/ejer.2016.63.16

Gupta, A., \& Sahu G.P. (2012). A Literature Review and Classification of Relationship Marketing Research. International Journal of Customer Relationship Marketing and Management, 3(1), 56-81. http://doi.org/10.4018/ijcrmm.2012010104

Hänninen, N., \& Karjaluoto, H. (2017). The effect of marketing communication on business relationship loyalty. Marketing Intelligence \& Planning, 35(4), 458-472. https://doi.org/10.1108/MIP-01-2016-0006

Hess, A., \& Melnyk, V. (2016). Pink or blue? The impact of gender cues on brand perceptions. European Journal of Marketing, 50(9/10), 1550-1574. https://doi.org/10.1108/EJM-11-2014-0723.

Jaciow, M. (2015). Generation Y-Young Europeans' Consumer Behavior. China-USA Business Review, 14(10): 515-522. https://doi.org/10.17265/1537-1514/2015.10.004

Jawed, M.S. (2016). Kavil Ramachandran: The 10 Commandments for Family Business. Journal of Family and Economic Issues, 37(3), 505-507. https://doi.org/10.1007/s10834-015-9472-1

Jovevski, D., \& Vasilevski, M. (2019). The impact of social media on building long-term relationships with the customers. Journal of Sustainable Development, 9(22), 47-63.

Kilian, T., Hennigs, N., \& Langner, S. (2012). Do Millennials read books or blogs? Introducing a media usage typology of the internet generation. Journal of Consumer Marketing, 29(2), 114-124. https://doi.org/ $10.1108 / 07363761211206366$

Kvidahl, M. (2015). Generations $Y$ and Z. What's the $X$ Factor? Meaningful marketing resonates most with kids and young adults. Gifts \& Decorative Accessories. Retrieved from https://www.giftsanddec.com/businessnews/generations-y-and-z/ on 10 January 2020.

Lazányi, K. (2014). Entrepreneurs of the future. Serbian Journal of Management, 9(2), 149-158. https://doi.org/10.5937/sjm9-6257

Leszczewska, K., Bitkowska, A., Kauf, S., Weiss, E., \& Kołodko, K. (2017). Success factors of Polish family businesses. International Journal of Management and Enterprise Development, 16(1/2), 128-149. https://doi.org/10.1504/IJMED.2017.10003453

Lim, J-S., Lim, K-S., \& Heinrichs, J.H. (2014). Gender and mobile access method differences of Millennials in social media evaluation and usage: an empirical test. Marketing Management Journal, 24(2), 124-135.

Lude, M., \& Prügl, R. (2018). Why the family business brand matters: brand authenticity and the family firm trust inference. Journal of Business Research, 89, 21-134, https://doi.org/10.1016/j.jbusres.2018.03.040.

Litz, R.A. (1995). The family business: Toward definitional clarity. Family Business Review, 8(2), 71-81. https://doi.org/10.1111/j.1741-6248.1995.00071.x

Luttrell, R., \& McGrath, K. (2016). The Millennial Mindset: Unravelling Fact from Fiction. Maryland: Rowman \& Littlefield Publishers.

Marjanski, A. (2015). Family Business Facing Challenges of Contemporary Economy. In Loera, M.R.C. and Marjański, A. (Eds.), The Challenges of Management in Turbulent Times. Global Issues from Local Perspective (pp. 41-48). Mexico City: Universidad de Occidente. 
Miller, N., McLeod, J.H., \& Oh, K.Y. (2001). Managing Family Businesses in Small Communities. Journal of Small Business Management, 39(1), 73-87. https://doi.org/10.1111/0447-2778.00007

Moore-Shay, E.S., \& Lutz, R.J. (1988). Intergenerational Influences in the Formation of Consumer Attitudes and Beliefs About the Marketplace: Mothers and Daughters, in Houston M. J. (Ed.), NA-Advances in Consumer Research Vol. 15 (pp. 461-467). Provo, UT: Association for Consumer Research.

Moorman, C., Zaltman, G., \& Deshpandé, R. (1992). Relationships between providers and users of market research: The dynamics of trust within and between organizations. Journal of Marketing Research, 29(3), 314328. http://dx.doi.org/10.2307/3172742

Morgan, R.M., \& Hunt, S.D. (1994). The Commitment-Trust Theory of Relationship Marketing. Journal of Marketing, 58, 20-38. https://doi.org/10.2307/1252308

Murphy, P.E., Laczniak, G.R., \& Wood, G. (2007). An ethical basis for relationship marketing: a virtue ethics perspective. European Journal of Marketing, 41(1/2), 37-57. https://doi.org/10.1108/0309056071071810

Nadkarni, A., \& Hofmann, S.G. (2012). Why do people use Facebook? Personality and Individual Differences, 52(3), 243-249. https://doi.org/10.1016/j.paid.2011.11.007

Ndubisi, N.O. (2006). Effect of gender on customer loyalty: A relationship marketing approach. Marketing Intelligence \& Planning, 24(1), 48-61. https://doi.org/10.1108/02634500610641552

Ndubisi, N.O. (2007). Relationship marketing and customer loyalty. Marketing Intelligence \& Planning, 25(1), 98106. https://doi.org/10.1108/02634500710722425

Ndubisi, N.O., \& Nataraajan, R. (2018). How the young adult consumer segment responds to trusty and committed marketing relationship. Psychology \& Marketing, 35(12), 923-935. https://doi.org/10.1002/mar.21145

Nikodemska-Wolowik, A.M., \& Bednarz J. (2019). Family Enterprises in the Context of Consumer Ethnocentrism and Relationship-Building. Problemy Zarzqdzania - Management Issues, 17(1), 77-92. https://doi.org/10.7172/1644-9584.81.4

Nikodemska-Wolowik, A.M., Bednarz J., \& Foreman J.R. (2019). Trends in young consumers' behaviour - implications for family enterprises. Economics and Sociology, 12(3), 11-24. https://doi.org/10.14254/2071789X.2019/12-3/1

Nikodemska-Wołowik, A.M., Bednarz, J., Wach, D., Little, J.P., \& Kubik, M.A. (2020). Building aware and unaware consumers' trust towards family business: Evidence from Poland. Entrepreneurial Business and Economics Review, 8(3), 135-154. https://doi.org/10.15678/EBER.2020.080308

Orth, U.R., \& Green, M.T. (2009). Consumer loyalty to family versus non-family business: The roles of store image, trust and satisfaction. Journal of Retailing and Consumer Services, 16(4), $248-259$. https://doi.org/10.1016/j.jretconser.2008.12.002

Parry, E., \& Battista, V. (2019). Generation Z in the UK: More of the Same-High Standards and Demands. In Scholz, C. and Rennig, A. (Eds.), Generations Z in Europe: The Changing Context of Managing People (pp. 89-107). Bingley, West Yorkshire: Emerald Publishing Limited. https://doi.org/10.1108/978-1-78973-491-120191013

Polce-Lynch, M., Myers, B.J., Kilmartin, C.T., Forsmann-Falck, R., \& Kliewer, W. (1998). Gender and age patterns in emotional expression, body image, and self-esteem: A qualitative analysis. Sex Roles, 38(11/12), 10251048. https://doi.org/10.1023/A:1018830727244

Powell, M., \& Ansic, D. (1997). Gender differences in risk behavioral in financial decision-making: an experimental analysis. Journal of Economic Psychology, 18, 605-628. https://doi.org/10.1016/S0167-4870(97)00026-3

Rosener, J.B. (1990). Ways women lead. Harvard Business Review, 68, 119-125.

See-To, E.W., \& Ho, K.K. (2014). Value co-creation and purchase intention in social network sites: The role of electronic Word-of-Mouth and trust-A theoretical analysis. Computers in Human Behavior, 31(1), 182-189. https://doi.org/10.1016/j.chb.2013.10.013

Shen, A., \& Tikoo, S. (2020). Family business identity, consumer product evaluations and firm size. Journal of Product \& Brand Management, Vol. ahead-of-print No. ahead-of-print. https://doi.org/10.1108/JPBM-10-2018-2057.

Soares, R.R., Zhang, T.T., Proença, J.F., \& Kandampully, J. (2017). Why are Generation Y consumers the most likely to complain and repurchase? Journal of Service Management, 28(3), 520-540. https://doi.org/10.1108/JOSM-08-2015-0256

Solomon, R.C., \& Flores, F. (2001). Building Trust in Business, Politics, Relationships, and Life. New York: Oxford University Press. 
Sun, Y., Zhang, Y., Shen, X., Wang, N., Zhang, X., \& Wu, Y. (2018). Understanding the trust building mechanisms in social media: Regulatory effectiveness, trust transfer, and gender difference. Aslib Journal of Information Management, 70(5), 498-517. https://doi.org/10.1108/AJIM-03-2018-0072

Triantafillidou, A., \& Siomkos, G. (2018). The impact of Facebook experience on consumers' behavioral brand engagement. Journal of Research in Interactive Marketing, 12(2), 164-192. https://doi.org/10.1108/JRIM-032017-0016

Turner, A. (2015). Generation Z: Technology and social interest. The Journal of Individual Psychology, 71(2), 103113. https://doi.org/10.1353/jip.2015.0021

Wach, K. (2020). A Typology of Small Business Growth Modelling: A Critical Literature Review. Entrepreneurial Business and Economics Review, 8(1), 159-184. https://doi.org/10.15678/EBER.2020.080109

Wielsma, A.J., \& Brunninge, O. (2019). "Who am I? Who are we?" Understanding the impact of family business identity on the development of individual and family identity in business families. Journal of Family Business Strategy, 10(1), 38-48. https://doi.org/10.1016/j.jfbs.2019.01.006

Wroblewska-Kazakin, A. (2014). Research on family businesses in Poland. Journal of Intercultural Management, 6(2), 63-72. https://doi.org/10.2478/joim-2014-0012

Zanon, J., Scholl-Grissemann, U., Kallmuenzer, A., Kleinhansl, N., \& Peters, M. (2019). How promoting a family firm image affects customer perception in the age of social media. Journal of Family Business Strategy, 10(1), 28-37. https://doi.org/10.1016/j.jfbs.2019.01.007

Zellweger, T.M., Eddleston, K.A., \& Kellermanns, F.W. (2010). Exploring the concept of familiness: Introducing family firm identity. Journal of Family Business Strategy, 1(1), 54-63. https://doi.org/10.1016/j.jfbs.2009.12.003

Zhang, T., Omran, B.A., \& Cobanoglu, C. (2017). Generation Y's positive and negative eWOM: Use of social media and mobile technology. International Journal of Contemporary Hospitality Management, 29(2), 732-776. https://doi.org/10.1108/IJCHM-10-2015-0611

\section{Authors}

The contribution share of authors is the following: Joanna Bednarz 30\%, Małgorzata Bartosik-Purgat 30\%, Tomasz Jastrzębski 20\%, Giuseppe T. Cirella 20\%. Bednarz prepared the concept of the article, identification of the research gap, literature review, interpretation of data, discussion, and conclusions. Bartosik-Purgat prepared the concept of the article, literature review, interpretation of data, discussion, and conclusions. Jastrzębski applied statistical methods, analysed results, and interpreted the data. Cirella prepared the literature review, then edited and revised the manuscript. All authors read and approved the final manuscript.

\section{Joanna Bednarz}

Habilitation, Doctor of Philosophy in Economics (2014, 2004 University of Gdansk); Head of the Department of International Business. Her research includes the competitiveness and internationalization of business entities, new trends in consumption, the behaviour of young consumers, brand and product management. She authored several books and scientific articles.

Correspondence to: Prof. UG dr hab. Joanna Bednarz, University of Gdansk, Faculty of Economics, Department of International Business, ul. Armii Krajowej 119/121, 81-824 Sopot, Poland, e-mail: joanna.bednarz@ug.edu.pl

ORCID 가 http://orcid.org/0000-0003-4695-0258

\section{Małgorzata Bartosik-Purgat}

Professor at the Department of International Management, Poznan University of Economics and Business. Her research includes cultural aspects in international business, international marketing, consumer behaviour and the significance of social media in a culturally diversified marketplace.

Correspondence to: prof. dr hab. Małorzata Bartosik-Purgat, Poznan University of Economics and Business, Department of International Management, al. Niepodległości 10, Poznań 61-875, Poland, e-mail: m.purgat@ue.poznan.pl

ORCID (1) http://orcid.org/0000-0003-3517-3617 


\section{Tomasz Jastrzębski}

Master of Econometrics and Econometrician at the Department of Econometrics, University of Gdansk, Poland. His research interests include econometrics, systemic risk, risk management and financial management. Correspondence to: Mgr Tomasz Jastrzębski, University of Gdansk, Faculty of Management, Department of Econometrics, ul. Armii Krajowej 101, 81-824 Sopot, Poland, e-mail: tomasz.jastrzebski@ug.edu.pl ORCID (1) http://orcid.org/0000-0003-1946-2865

\section{Giuseppe T. Cirella}

Habilitation in Economics, Doctor of Philosophy in Engineering (2020, University of Gdansk, Poland; 2010, Griffith University, Australia); Professor at the University of Gdansk, Poland. His research interests include economic geography, economic development, society studies and sustainability.

Correspondence to: Dr hab. Giuseppe T. Cirella, University of Gdansk, Faculty of Economics, Department of Transport Economics, ul. Armii Krajowej 119/121, 81-824 Sopot, Poland, e-mail: gt.cirella@ug.edu.pl ORCID (1) http://orcid.org/0000-0002-0810-0589

\section{Acknowledgements and Financial Disclosure}

The article was prepared and funded by Poland's National Science Centre (Narodowe Centrum Nauki - NCN) No. 2016/21/B/HS4/01600.

\section{Conflict of Interest}

The authors declare that the research was conducted in the absence of any commercial or financial relationships that could be construed as a potential conflict of interest.

\section{Copyright and License}

This article is published under the terms of the Creative Commons

Attribution - NoDerivs (CC BY-ND 4.0) License

http://creativecommons.org/licenses/by-nd/4.0/ 